\title{
Benthic energy flow during a simulated autumn bloom sedimentation
}

\author{
Gerhard Graf \\ Institut für Meereskunde, Düsternbrooker Weg 20, D-2300 Kiel, Federal Republic of Germany
}

\begin{abstract}
Sedimentation of an autumn diatom bloom and its effect on sediment was simulated in the laboratory. Benthic response was similar to that observed in previous field studies: (1) a response within hours, (2) a rise of the chemocline, and (3) a change to pronounced anaerobiosis. Benthic metabolism was affected down to at least $7 \mathrm{~cm}$ sediment depth. Significantly more organic matter was consumed than was added by diatoms. Sediment oxygen consumption explained $<3 \%$ of the organic matter used, while heat production explained $89 \%$ of the burned material integrated over $7 \mathrm{~cm}$ sediment depth. The geochemical model of oxidizing organic matter is criticized. Development of ATP-biomass was in phase with the observed pattern of heat production. Efficiency of benthic response (P/C) was 50 to $60 \%$ in the surface and $<40 \%$ in deeper sediment strata. The energy flow equation fitted within a range of $10 \%$.
\end{abstract}

\section{INTRODUCTION}

A significant part of pelagic organic matter production is channeled into the benthic food web creating a tight coupling of pelagic and benthic systems (Hargrave 1980). The rapid response of the benthic community to sedimentation events was described by Graf et al. (1982) and simulated in a laboratory experiment by Kelly \& Nixon (1984). Previous investigations were mainly related to the sediment-water interface, and for practical reasons in field studies could not achieve a temporal resolution of less than $1 \mathrm{wk}$. Several questions remained unanswered: for example, how fast is the response, and to what depth is the sediment affected? Therefore, we decided to simulate sedimentation events in the laboratory during seasons characterized by bloom sedimentation. The first simulation was carried out for an autumn bloom, as contradictory observations, i.e. response as well as non-response, have been reported from field studies (Hargrave 1980, Graf et al. 1983, Czytrich et al. 1986).

In the field studies, apparent vertical sedimentation was not sufficient, and lateral advection of organic matter had to be invoked to balance material and energy budgets (Graf et al. 1984, Hargrave \& Phillips 1986). A horizontal advection factor (i.e. the ratio of laterally supplied near-bottom organic matter to vertically sedimented organic matter) of 4 to 7 during a bloom period was estimated by Graf et al. (1983), and for the same station on a slope in Kiel Bight, Balzer et al. (1986) calculated an annual advection factor of 2 . Therefore, the actual sedimentation input to the bottom as determined by sediment traps remains uncertain. A laboratory experiment excludes lateral advection and can exactly quantify the carbon input. Under these conditions it should also be possible to test direct calorimetry as a method of estimating carbon flow, and to compare the results with oxygen consumption by the sediment surface. If, additionally, biomass development is determined, the efficiency of the benthic response can be calculated.

\section{MATERIAL AND METHODS}

Samples were collected on 3 Dec 1984 from the 'Hausgarten' area (western Kiel Bight, Baltic Sea) at $18 \mathrm{~m}$ water depth. Two box cores $(50 \times 50 \mathrm{~cm})$ were taken, along with $100 \mathrm{l}$ water from close to the sediment surface using a Niskin bottle. In situ temperature was $8^{\circ} \mathrm{C}$ and salinity $18.7 \%$. From the 2 box cores 20 subcores, $15 \mathrm{~cm}$ deep and with 10 to $15 \mathrm{~cm}$ of overlying water, were taken using plexiglas tubes of $10 \mathrm{~cm}$ inside diameter. The bottom of each core was stoppered with 'Delrin'.

In the laboratory the 20 cores were put into a dark water bath regulated at in situ temperature. The cores were permitted to equilibrate for $2^{1 / 2} \mathrm{~d}$ to lab condi- 
tions. They were closed by a piston equipped with a magnetic stirrer. The covers had 2 connections for a flow-through system ( $6 \mathrm{~mm}$ inner diameter) and a small outflow ( $3 \mathrm{~mm}$ inner diameter) for taking water samples for oxygen determinations. Cores were connected to a flow-through system, in 5 separate circuits, driven by a multipurpose peristaltic pump (Desaga), to supply the cores with oxygen-saturated seawater.

Algae were cultivated as described by Smetacek et al. (1980) and consisted of an almost pure culture of the diatom genus Skeletonema. The diatoms were harvested using a $20 \mu \mathrm{m}$ plankton net and were concentrated by gentle centrifugation. The concentrated diatoms were warmed to $40^{\circ} \mathrm{C}$ and shocked by cooling them to $0^{\circ} \mathrm{C}$. After repeating this procedure the diatoms had lost their ATP content. Cores were fed by slowly pipetting $6.4 \mathrm{ml}$ of algal suspension into the water immediately above the sediment surface. The suspension first formed a 3 to $4 \mathrm{~cm}$ high 'nepheloidal layer', but then settled within $3 \mathrm{~h}$ into an evenly distributed green carpet on the sediment surface. Aliquots of the algae were kept frozen for analysis of chlorophyll $a$, protein, and organic matter (OM). On 6 Dec (Day 0) the first 4 cores were analysed. The following day (Day 1) the cores were fed as described above. On each of Days 2, 4, 6, and 9, 4 cores were sectioned to analyse ATP-biomass, OM, and chlorophyll $a$ in the sediment. Oxygen consumption and redox potential were measured on all remaining cores, i.e. 20 replicates on Day 0 , 16 on Day 2 etc., down to 4 on Day 9.

Redox potential was measured with an Eh-electrode (Ingold Pt-4800-M5). Oxygen consumption of individual cores was measured overnight. The cores were disconnected from the flow-through system and $50 \mathrm{ml}$ from the overlying water was siphoned into a Winkler bottle at the beginning and end of 8 to $12 \mathrm{~h}$ of incubation. Oxygen determinations were carried out as described by Grashoff (1976). Heat production of the 0 to $1 \mathrm{~cm}$ sediment layer was measured using the Pamatmat double twin calorimeter (Pamatmat 1978) as described by Graf et al. (1982). The deeper layers (1 to 2,2 to 3,3 to 4 , and 6 to $7 \mathrm{~cm}$ ) were measured in an LKB batch calorimeter (Type 10700-2). To increase the numbers of heat production measurements, a second batch calorimeter was built from an LKB flow-through calorimeter (Type 10700-1). Both instruments were encased in a PVC plastic box submerged in a water bath creating a second double twin calorimeter. Sample size was $4 \mathrm{~cm}^{3}$. The method of heat production measurement in anaerobic sediments is described by Graf \& Bengtsson (1984). All calorimetric measurements were run at in situ temperature. Of the 4 cores analysed on one day, the one with oxygen consumption values closest to the mean of the 4 values was chosen for calorimetry. ATP-biomass was analysed according to Pamatmat et al. (1981). From each layer of 4 cores, 5 replicates and 3 controls for recovery rates were analysed, i.e. every point in Fig. $2 \mathrm{C}$ comprises 20 replicates and 12 controls.

The remainder of similar layers of the 4 cores was combined, homogenized and analysed for chlorophyll $a\left(3 \mathrm{~cm}^{3}\right)$ and $O M\left(5 \mathrm{~cm}^{3}\right)$. Chlorophyll a was analysed according to Jeffrey \& Humphrey (1975). Organic matter was determined as weight loss on ignition at $500^{\circ} \mathrm{C}$ after drying to constant weight at $65^{\circ} \mathrm{C}$. Protein of the added algae was analysed according to Lowry et al. (1951)

\section{RESULTS}

The $6.4 \mathrm{ml}$ diatom culture added to one core of $78.5 \mathrm{~cm}^{2}$ contained $14.4 \mathrm{mg} \mathrm{OM} \mathrm{ml} \mathrm{ml}^{-1}, 3.8 \mathrm{mg}$ protein

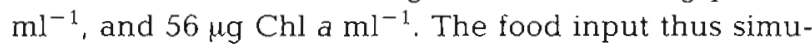
lated a sedimentation event of $5.8 \mathrm{~g} \mathrm{C} \mathrm{m}^{-2}$, assuming $\mathrm{C}: \mathrm{OM}=1: 2$. As soon as Day $2,1 \mathrm{~d}$ after feeding, the top $2 \mathrm{~cm}$ of the sediment showed a significant increase of about $2 \mu \mathrm{g} \mathrm{cm}^{-3} \mathrm{Chl} a$, and down to the 3 to $4 \mathrm{~cm}$ layer a slight increase is also visible (Fig. 1), thus

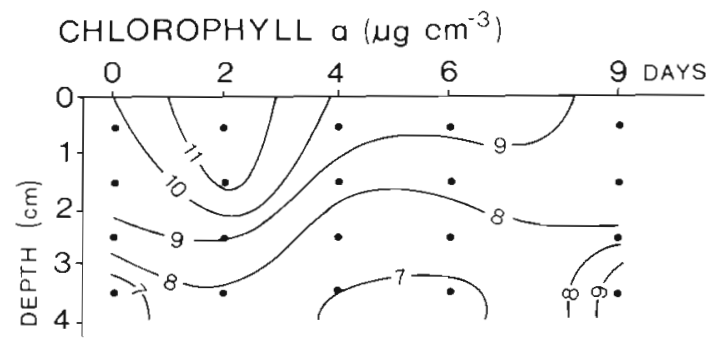

Fig. 1. Variation with time and depth of chlorophyll a ( $\mu \mathrm{g}$ $\mathrm{cm}^{-3}$ ) in the sediment. Cores were fed on Day 1

accounting for the added $4.6 \mu \mathrm{g} \mathrm{cm}^{-2} \mathrm{Chl} \mathrm{a}$. It is therefore demonstrated that chlorophyll values in the sediment are directly comparable with the amounts in the algal suspension. During the $9 \mathrm{~d}$ experiment chlorophyll $a$ in the sediment surface $(0$ to $1 \mathrm{~cm})$ decreased to initial starting (non-bloom) values. An increase in deeper sediment layers after $9 \mathrm{~d}(3$ to $4 \mathrm{~cm})$ is indicated by only one value. During December no benthic-originated chlorophyll a can be expected at this station (Schulz 1983).

Oxygen consumption of the sediment cores increased by a factor of 5 within $1 \mathrm{~d}$ after feeding (Fig. 2 A). The effect was so strong that oxygen concentrations after the first incubation period were zero. Thus, rates would have been higher if the oxygen supply was not exhausted. After the first peak, however, oxygen consumption decreased and on Day 6 it was no longer significantly different from Day 0 .

Heat production also increased in the sediment surface $(0$ to $1 \mathrm{~cm})$, by a factor of 5 , but slowly up to Day 6 

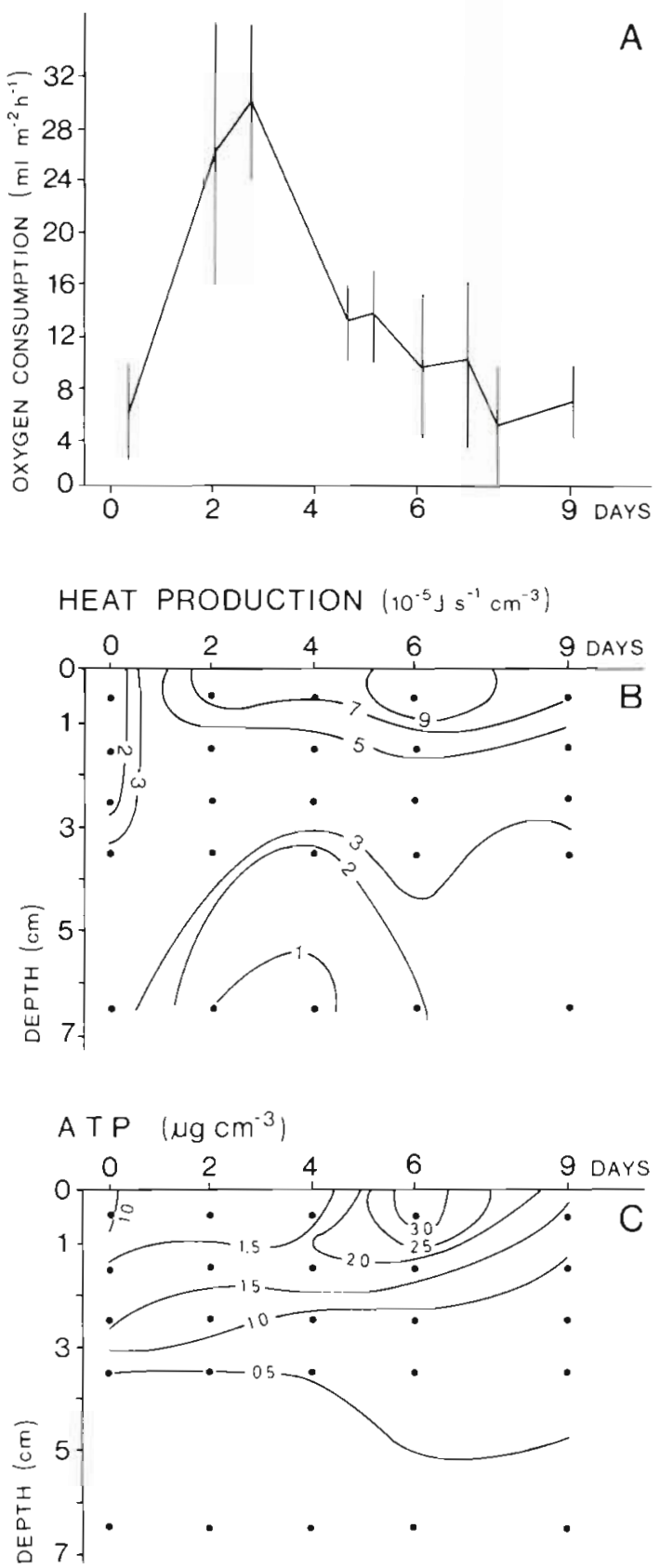

Fig. 2. (A) Time course of oxygen consumption in the sediment surface. Variation with time and depth in the sediment of (B) heat production and (C) ATP-biomass

(Fig. 2 B). Response to the added organic matter after $9 \mathrm{~d}$ was still not over. Increase of heat production occurred in the top $3 \mathrm{~cm}$ of the sediment. Surprisingly, an opposite effect was visible in the deeper sediment strata, where heat production decreased by a factor of 4 , i.e. the activity profile in the sediment was completely inverted by the food input.

For benthic ATP-biomass, on Day 0 a subsurface maxinum (1 to $3 \mathrm{~cm}$ ) was visible. ATP-biomass increased slowly until Day 4 in the top sediment layer

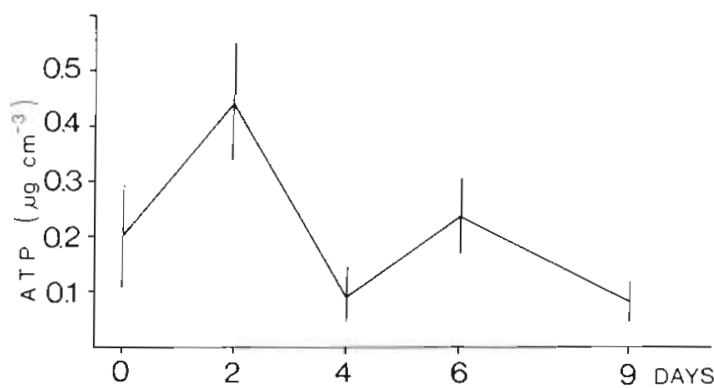

Fig. 3. Time course of ATP-biomass in the 6 to $7 \mathrm{~cm}$ sediment layer

and then doubled within the next $2 \mathrm{~d}$ creating a surface maximum a factor 3.5 greater than starting conditions. Smaller, but significant, changes occurred in the deeper sediment strata (Fig. 3). In the 6 to $7 \mathrm{~cm}$ layer a doubling in ATP-biomass was visible after only $2 \mathrm{~d}$. After $9 \mathrm{~d}$ only half of the original ATP-biomass was left.

The dramatic increase in benthic activity and biomass was accompanied by a decrease of redox potential in the sediment surface (Fig. 4). The chemocline

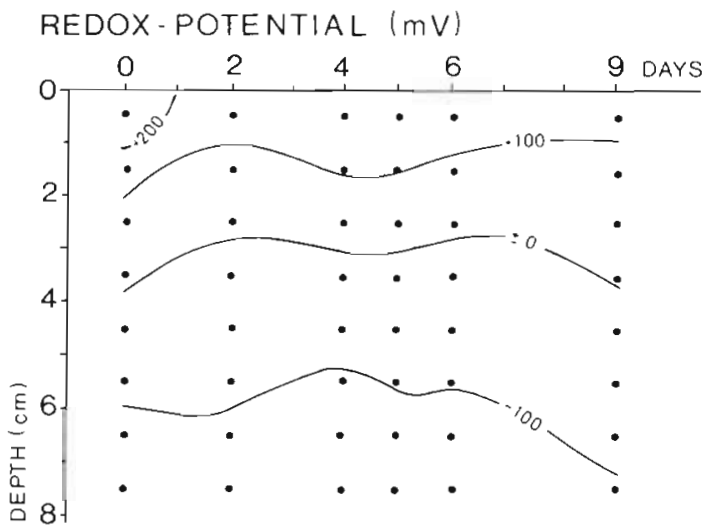

Fig. 4. Variation with time and depth of redox potential in the sediment. The chemocline $(\mathrm{Eh}=+100 \mathrm{mV})$ rose about $1 \mathrm{~cm}$. after feeding

$(\mathrm{Eh}=+100 \mathrm{mV})$ rose about $1 \mathrm{~cm}$ closer to the sediment surface, below which only slight changes in redox conditions can be seen. Probably, the chemocline did even temporarily reach the sediment surface. The cores in the deeper sediment strata became more anoxic only on Day 9.

The ratio of heat production/ATP (Fig. 5) also demonstrates that the effect of the added diatoms penetrated deeply into the sediment. It indicates ATPturnover, which itself is dependent on the type of metabolism, being higher for fermentation and anaerobiosis than for aerobiosis (Pamatmat et al. 1981). On Day 2 the metabolic type of the organisms was affected down to at least $7 \mathrm{~cm}$ sediment depth. At the sediment surface ATP-turnover increased by a factor 


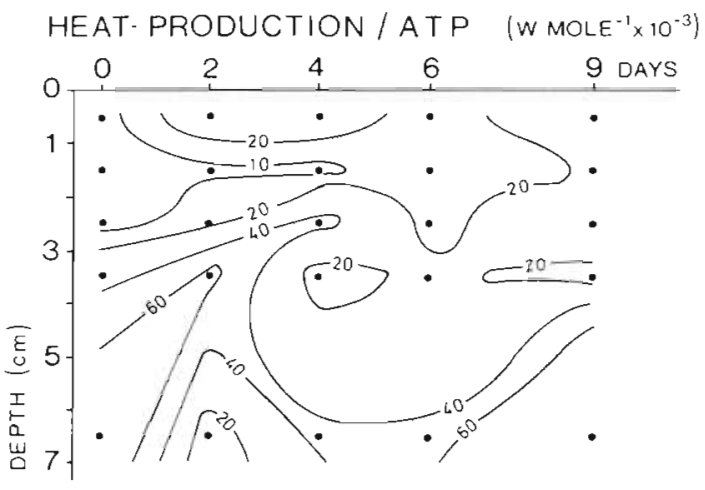

Fig. 5. Variation with time and depth of the ratio heat production/ATP, indicating changes in the type of metabolism, which is affected down to $7 \mathrm{~cm}$ sediment depth

Table 1. Energy and material budget

\begin{tabular}{|c|c|c|c|}
\hline & OXYGEN & HEAT & ORGANIC MATTER \\
\hline \multirow[b]{2}{*}{$\begin{array}{l}\text { Consumplion or } \\
\text { production } \\
\text { over } 9 \mathrm{~d}\end{array}$} & \multirow[b]{2}{*}{$439 \mu \mathrm{g} \mathrm{O}_{2} \mathrm{~cm}^{-2}$} & \multicolumn{2}{|c|}{ integrated over $7 \mathrm{~cm}$ depth } \\
\hline & & $26.3 \mathrm{~J} \mathrm{~cm}^{-3}$ & $\begin{array}{c}13 \text { LOSB } \\
1.47 \mathrm{mg} \mathrm{OMMcm}\end{array}$ \\
\hline Assumption & $\mathrm{RO} * 1$ & $1 \mathrm{mgC} \cdot 40 \mathrm{~J}$ & C: $O M=1: 2$ \\
\hline $\begin{array}{l}\text { Carbon- } \\
\text { equivalent }\end{array}$ & $0.146 \mathrm{mg} \mathrm{C} \mathrm{cm}^{-2}$ & $0.66 \mathrm{mg} \mathrm{C} \mathrm{cm}^{-3}$ & $0.74 \mathrm{mg} \mathrm{C} \mathrm{cm}^{-3}$ \\
\hline
\end{tabular}

of 4 . On Day 9 the earlier situation began to return, with a strong gradient between 3 and $5 \mathrm{~cm}$.

During the experiment much more organic matter was burned than was added in the form of diatoms (Table 1). Integrated over $7 \mathrm{~cm}$ depth and $9 \mathrm{~d}, 1.3 \mathrm{mg}$ $O \mathrm{M} \mathrm{cm}^{-3}$ of the original $21.1 \mathrm{mg} \mathrm{OM} \mathrm{cm} \mathrm{mas}^{-3}$ was consumed in the sediment which, together with the bloom material (0.17 $\left.\mathrm{mg} \mathrm{OM} \mathrm{cm}^{-3}\right)$ sums to $1.47 \mathrm{mg} \mathrm{OM} \mathrm{cm}^{-3}$. Assuming the same factors as above, carbon used per $\mathrm{cm}^{3}$ was $0.74 \mathrm{mg}$.

If the same integration is carried out for heat production, $26.3 \mathrm{~J} \mathrm{~cm}^{-3}$ were produced, which is equivalent to the combustion of $0.66 \mathrm{mg} \mathrm{C} \mathrm{cm}^{-3}$, assuming that $1 \mathrm{~g}$ phytoplankton $C$ has a combustion value of $40 \mathrm{~kJ}$ (Salonen et al. 1976). Thus, heat production explains $89 \%$ of the lost OM.

For oxygen, $439 \mu \mathrm{g} \mathrm{O}_{2} \mathrm{~cm}^{-2}$ were consumed within the $9 \mathrm{~d}$. Even assuming that oxygen was used only for respiration $(R Q=1)$, the carbon equivalent is only $0.146 \mathrm{mg} \mathrm{C} \mathrm{cm}^{-2}$. Thus, integrated over $7 \mathrm{~cm}$ sediment depth, it explains less than $3 \%$ of the lost organic matter.

If oxygen consumption is compared with heat production in the top sediment layer $(0$ to $1 \mathrm{~cm})$ only $157 . \mathrm{J}$ $\mathrm{cm}^{-3}$, equivalent to $1.4 \mathrm{mg} \mathrm{C} \mathrm{cm}{ }^{-3}$ ), it can account for only $10 \%$ of surface heat production (Table 2 ). In other words, total core oxygen uptake produces the same amount of heat as $1 \mathrm{~mm}$ sediment layer.
Table 2. Carbon budget of the sediment surface $(0$ to $1 \mathrm{~cm})$ over $9 \mathrm{~d}$

\begin{tabular}{|c|c|}
\hline loss of carbon & $1.1 \mathrm{mg} \mathrm{C} \mathrm{cm}^{-3}$ \\
\hline $1 / 2$ of bloom & $0.3 \mathrm{mg} \mathrm{C} \mathrm{cm}^{-3}$ \\
\hline total carbon equivalent & $1.4 \mathrm{mg} \mathrm{C} \mathrm{cm}^{-3}=56 \mathrm{~J} \mathrm{~cm}^{-3}$ \\
\hline measured heat production & $57 \mathrm{Jcm}^{3}$ \\
\hline bromass increase & $80 \mu \mathrm{g} \mathrm{cm} \mathrm{cm}^{-3}-32 \mathrm{~J} \mathrm{~cm}^{-3}$ \\
\hline
\end{tabular}

\section{DISCUSSION}

\section{Simulation experiment}

The experiment simulated a sedimentation event in early December comparable to that in a field study in 1983 (Czytrich et al. 1986, Noji et al. 1986). Both the species involved (Skeletonema spp.) and the amount of added carbon $\left(5.8\right.$ vs $\left.8.9 \mathrm{~g} \mathrm{C} \mathrm{m}^{-2}\right)$ are comparable. At first glance, the response of the sediment community in the laboratory is similar to that observed during several spring field experiments (Graf 1987), or that observed during the above-mentioned autumn bloom sedimentation in 1983: (1) an immediate increase in benthic activity in terms of oxygen consumption and heat production, (2) an rise of the chemocline, and (3) a change towards a more pronounced anaerobic metabolism.

The time resolution during the experiment was days and demonstrates that the response most likely begins within hours after food input, and can cause severe oxygen deficiency. The latter effect has also been described after spring bloom sedimentation events in the field (von Bodungen 1975). The extreme rapidity of reaction demonstrates that even in a field study with $1 \mathrm{wk}$ sampling intervals, there is a realistic chance of completely missing such events.

Contrary to the present findings Hargrave (1980) and Czytrich et al. (1986) reported a non-response to autumn bloom sedimentation. To account for the difference, simulation conditions during the experiment should be considered. (1) During December a strong temperature decrease from about 8 to $4{ }^{\circ} \mathrm{C}$ occurs in Kiel Bight, which was not simulated in the lab. Thus, a response in the field would have been slowed down. (2) A more important effect will be caused by the lack of turbulence in the experimental set up, which allows direct contact of diatoms with the sediment surface and immediate consumption by benthic organisms. (3) Consumption may have been enhanced by the treatment of the diatom cells, which may have caused more cell damage than naturally occurs at sediment surfaces.

In stormy autumn periods it is possible that an autumn bloom, although disappearing from the water 
column, does not reach the sediment or is not incorporated. Instead, the material may be resuspended, creating high quality detritus in the water column, which is not decomposed (Smetacek \& Hendrikson 1979). The laboratory experiment, however, shows that the benthic community can consume the food quickly once settled on the sediment.

\section{Deep-reaching effect}

The surprising result of the experiment is the response of organisms in deeper sediment layers only $1 \mathrm{~d}$ after feeding. In 6 to $7 \mathrm{~cm}$ depth a doubling in ATPbiomass (Fig. 4) occurred, although heat production had already decreased (Fig. 2 B), and the inversion of the activity profile in the sediment had started. How can the organisms 'know' that something is happening on the sediment surface? A transport of particles as evidenced by chlorophyll a values (Fig. 1) may influence the top 2 or $3 \mathrm{~cm}$ immediately. Mainly responsible for the reworking of particles are Pektinaria koreni, Nephthys spp., and Macoma balthica, which all occurred in almost every core with, however, variable abundance. A quantitative description of the macrofauna of this station is given by Graf et al. (1984). Deeper sediment strata can only be reached by porewater exchange and transport in the liquid phase.

As mentioned before, much more carbon was burned than was added by the bloom simulation. Thus, explaining the doubling of ATP-biomass in 6 to $7 \mathrm{~cm}$ sediment depth by the feeding effect implies that a small amount of essential material reached this layer and that it increased the availability of older organic matter, initiating cooxidation. However, other explanations cannot be excluded. (1) Small changes in chemical conditions, as evidenced by the rise of the chemocline, may activate microorganisms better adapted to the new conditions. This mechanism could explain a deep-reaching effect without a 'long-distance' transport of matter. (2) It cannot be ruled out that the increase of ATP-biomass has nothing to do with the present experiment, but is an effect of natural blooms which may have settled in the field during November, before the samples were taken.

The heat production/ATP ratio (Fig. 5) suggests that at least from Day 4 the sediment down to $7 \mathrm{~cm}$ depth was influenced by the experiment. The increase of chlorophyll $a$ in the 3 to $4 \mathrm{~cm}$ layer on Day 9 may indicate that particles had by then been incorporated down to this depth. A bioturbation rate of 4 to $5 \mathrm{~mm} \mathrm{~d}^{-1}$ may be calculated. This rate is comparable with values given by Lee \& Swartz (1980) and by Mahaut \& Graf (in press), but the rate is high when compared with the value of $1 \mathrm{~mm} \mathrm{~d}^{-1}$ observed in the field after the sedimentation of a Caratium bloom (Czytrich et al. 1986). It is obvious that the influence of settling blooms on deeper sediment layers must be investigated employing special tracer techniques for both liquid and particle transport in the sediment. The interpretation offered here is a first hypothesis.

\section{Oxygen versus heat budget}

Oxygen consumption by the sediment is a consequence of oxygen respiration, chemosynthesis, and chemical oxidation. Since Revsbech et al. (1979) demonstrated with microelectrodes that oxygen penetrates the sediment only a few millimeters, it is obvious that in coastal waters the above-mentioned oxygen consuming processes are bound to a very thin layer on the sediment surface and to wall layers of infaunal burrows and tubes. On Day 0 of this experiment oxygen consumption explains the sediment activity of the upper $3 \mathrm{~mm}$. After food was added it is only $1 \mathrm{~mm}$. For comparable sediments Forster (1985) found 2 to $3 \mathrm{~mm}$ using the Revsbech microelectrodes.

The sediment below 1 to $3 \mathrm{~mm}$ is free of oxygen, forcing the organisms to anaerobic metabolism. It is believed, however, especially from the geochemical point of view, that all reduced substances created by anaerobic metabolism are oxidized as soon as they come into contact with oxygen. This means anaerobic processes are indirectly also measured by oxygen consumption, but with a time lag because some time is needed to transport these substances to the sediment surface. In the present study it is evident that the reaction of organisms is in phase with oxygen consumption only in the initial stages. The doubling in ATP-biomass from Day 4 to 6 , which must have developed anaerobically, is by no means reflected in the oxygen consumption.

Oxygen consumption explains less than $3 \%$ of the organic matter burned. Even assuming that the abovementioned time lag was not yet complete as is indicated by the still raised chemocline, other explanations have to be considered. (1) Determinations of oxygen consumption may be underestimates because of oxygen production from hydrogen peroxide by catalase activity (Pamatmat in press). (2) Reduced substances may not be oxidized in the thin surface sediment layer but only much later in the water column. Nixon et al. (1976) and Christensen et al. (1983) observed a release of dissolved organic nitrogen from sediments, which converted to dissolved organic carbon would explain a major part of the carbon budgets. In this case oxygen budgets must consider the whole system including all lateral advection and other boundary layers. (3) Fermentation processes, which are neglected in the 
geochemical model of oxidizing organic matter, may be much more important than expected. Strong discrepancies between $\mathrm{O}_{2}$ consumption and $\mathrm{CO}_{2}$ release of the sediment have been reported (Pamatmat 1968, Hargrave \& Phillips 1981). Hanson \& Tenore (1981) demonstrated that the $\mathrm{CO}_{2}: \mathrm{O}_{2}$ ratio can be $50: 1$ when macrophyte debris is decomposed. Furthermore, fermentation end products are needed to explain sulphate respiration. However, it is unknown how much organic matter is needed to create all the substrates necessary.

Heat production in the sediment surface $(0$ to $1 \mathrm{~cm})$ was in phase with the development of ATP-biomass and explains $89 \%$ of the lost OM. Because there were no replicates in the heat production measurements, there is no point in discussing the $11 \%$ difference between $O M$ and heat production budgets. Theoretically an underestimate can be expected for the following reasons: (1) The combustion value of $40 \mathrm{~kJ} \mathrm{~g} \mathrm{C}^{-1}$ is appropriate for fresh phytoplankton. Older organic material being oxidized together with diatoms will have had lower combustion values. (2) The accumulation of reduced substances (e.g. $\mathrm{H}_{2} \mathrm{~S}$ ) may lead to an underestimate because the main heat-releasing process is associated with oxidation of the end product. An example is given by Forster (1985):

$$
\begin{aligned}
& \mathrm{C}_{6} \mathrm{H}_{12} \mathrm{O}_{6}+3 \mathrm{SO}_{4}^{2-} \rightarrow 6 \mathrm{CO}_{2}+6 \mathrm{H}_{2} \mathrm{O}+3 \mathrm{~S}^{2-} \\
& \Delta \mathrm{H}=-315 \mathrm{~kJ} \text { mole } \\
& 3 \mathrm{~S}^{2-}+6 \mathrm{O}_{2} \rightarrow 3 \mathrm{SO}_{4}^{2-} \\
& \Delta \mathrm{H}=-2538 \mathrm{~kJ} \mathrm{~mole}^{-1}
\end{aligned}
$$

However, the heat budget and the redox conditions suggest that no large quantities of reduced substances were accumulated. Heat production in the sediment is enthalpy change and comprises the heat of all chemical reactions in the sample. At the present state of knowledge, a compilation of all known chemical reactions in the sediment and a calculation of the theoretical amount of heat releases does not look promising. We do not know the importance of entropy changes and most likely we are not aware of all the chemical reactions occurring in the system. The present experiment mainly demonstrates that total heat release is a realistic estimate of organic matter flow through a system even when conditions are mainly anaerobic.

\section{Energetic considerations}

Since the famous experiments of Rubner (1894) with dogs, it is known that heat release (Q) or respiration (R) of an animal is equivalent to the difference between combustion energy of food (C) and the combustion energy of faeces (F) and urine (U). A change in biomass (P) was not to be expected in his experiments. This result is an early formulation of the energy flow equation

$$
\mathrm{C}=\mathrm{P}+\mathrm{R}+\mathrm{F}+\mathrm{U}
$$

The thermodynamic derivation of this equation (Wiegert 1968) equals $Q=R$, as theoretically was calculated by Ivlev (1934). For marine organisms this was directly shown by Pamatmat (1978). In our experiment it is now possible to install the energy flow equation on a community level. In the case of a marine soft-bottom community $\mathrm{F}$ and $\mathrm{U}$ are food for other organisms. Only that part of $U$ being released into the water is unknown and is neglected for the following considerations. Thus $\mathrm{C}=\mathrm{P}+\mathrm{Q}$. Substituting values from Table $2,56=3.2$ +57 , i.e. equation fits within a range of $10 \%$.

Production after $9 \mathrm{~d}$ is rather low. The first biomass increase from Day 0 to Day 6 was much more significant and very efficient with $\mathrm{P} / \mathrm{C}=59 \% . \mathrm{P} / \mathrm{C}$ for the 1 to $2 \mathrm{~cm}$ layer from Day 0 to Day 4 was $58 \%$. Both values are well within the range given for the efficiencies of protozoa (Finlay 1978). Only the increase in biomass in deeper sediment layers $(6$ to $7 \mathrm{~cm}$ ) is less efficient $(\mathrm{P} / \mathrm{C}=38 \%)$.

In summary, reasonable values for utilized organic matter and growth efficiencies are found when heat production measurements are used as a direct measure of energy flow.

Acknowledgements. I am indebted to Professor Dr S. Gerlach, Professor Dr M. M. Pamatmat, and Dr P. Jensen for helpful comments on the manuscript; $W$. Koeve and N. Mumm for assistance during the experiment; and $D$. Schütze for assistance with chemical analyses. $H$. Kähler-Vogel drew the figures. This work was supported by the Deutsche Forschungsgemeinschaft'.

\section{LITERATURE CITED}

Balzer, W., Pollehne, F., Erlenkeuser, H. (1986). Cycling of organic carbon in a coastal maxine system. In: Sly, P. G. (ed.) Sediments and water interactions. Springer-Verlag, New York, p. 323-328

Bodungen, B. von (1975). Der Jahresgang der Nährsalze und der Primärproduktion des Planktons in der Kieler Bucht unter Berücksichtigung der Hydrographie. Ph.D. thesis, Kiel Univ.

Christensen, J. P., Rowe, G. T., Clifford, C. H. (1983). The possible importance of primary amino nitrogen in nitrogen regeneration by coastal manine sediments in Buzzard Bay, Massachusetts. Int. Revue ges. Hydrobiol. 68: 501-512

Czytrich, H., Eversberg, U., Graf, G. (1986). Interaction between pelagial and benthal during autumn in Kiel Bight. II. Benthic activity and chemical composition of organic matter. Ophelia 26: 123-133

Finlay, B. J. (1978). Community production and respiration by ciliated protozoa in the benthos of a small eutrophic lake. Freshwat. Biol. 8: 327-341

Forster, S. (1985). Was bedeutet 'Sauerstoffzehrung' bei marinen Sedimenten. M.S. thesis, Kiel Univ. 
Graf, G. (1987). Benthic response to the annual sedimentation pattern. In: Rumohr, J., Walger, E., Zejtzschel, B. (ed.) Lecture notes on coastal and estuarine studies, Vol. 13. Seawater-sediment interactions in coastal waters. An interdisciplinary approach. Springer-Verlag, New York, p. $84-92$

Graf, G., Bengtsson, W. (1984). Heat production, activity of the electron-transport-system (ETS), the ratio heat production/ ETS-activity, and ATP-turnover as usefull tools in benthic ecological field studies. Arch. Hydrobiol. Beih. Ergeb. Limnol. 19: 249-256

Graf, G., Bengtsson, W., Diesner, U., Theede, H. (1982). Benthic response to sedimentation of a spring phytoplankton bloom: process and budget. Mar. Biol. 67: 201-208

Graf, G., Bengtsson, W., Faubel, A., Meyer-Reil, L.-A., Schulz, R., Theede, H., Thiel, H. (1984). The importance of the spring phytoplankton bloom for the benthic system of the Kiel Bight. Rapp. P.-v. Réun. Cons. int. Explor. Mer 183: $136-143$

Graf, G., Schulz, R., Peinert, R., Meyer-Reil, L.-A. (1983). Benthic response to sedimentation events during autumn to spring at a shallow-water station in the Western Kiel Bight. Mar. Biol. 77: 235-246

Grasshoff, K. (1976). Methods of seawater analysis. Verlag Chemie, Weinheim

Hanson, R. B., Tenore, K. R. (1981). Microbial metabolism and incorporation by the polychaete Capitella capitata of aerobically and anaerobically decomposed detritus. Mar Ecol. Prog. Ser. 6: 299-307

Hargrave, B. $T$ (1980). Factors affecting the flux of organic matter to sediments in a marine bay. In: Tenore, K. R., Coull, B. C. (ed.) Marine benthic dynamics. Univ. South Carolina Press, Columbia, p. 243-263

Hargrave, B. T., Phillips, G. A. (1981). Annual in situ carbon dioxide and oxygen flux across a subtidal marine sediment. Estuar. coast. Shelf Scj. 12: 725-737

Hargrave, B. T., Phillips, G. A. (1986). Dynamics of the benthic food web in St. Georges Bay, southern Gulf of St. Lawrence. Mar. Ecol. Prog. Ser. 31: 277-294

Ivlev, V.-S. (1934). Eine Mikromethode zur Bestimmung des Kaloriengehaltes von Nährstoffen. Biochem. Z. 275: 51-55

Jeffrey, S. W., Humphrey, G. F. (1975). New spectrophotometric equations for determining chlorophylls $a, b, c 1$, and $c 2$ in higher plants, algae and natural phytoplankton. Biochem. Physiol. Ptlanz.: 167

Kelly, J. R., Nixon, S. W (1984). Experimental studies of the effect of organic deposition on the metabolism of a coastal marine bottom community. Mar. Ecol. Prog. Ser. 17: $157-169$

Lee, H., II, Swartz, R. C. (1980). Biological processes affecting the distribution of pollutants in marine sediments. Part II. Biodeposition and bioturbation. In: Baker, R. A. (ed.) Contaminants and sediments, Vol. 2. Ann Arbor Science Publishers, Ann Arbor, p. 555-606

Lowry, O H., Rosebrough, N. J., Farr, A. L., Randall, R. J (1951). Protein measurement with the Folin Phenol Reagent. J. biol. Chem. 193: 261-275

Mahaut, M.-L., Graf, G. (1987). A luminophore tracer technique for bioturbation studies. Oceanologica Acta (in press)

Nixon, S. W., Oviatt, C. A., Hale, S. S. (1976). Nitrogen regeneration and the metabolism of coastal marine bottom communities. In: Anderson, J. M., McFadyen, A. (ed.) The role of terrestrial and aquatic organisms in decomposition processes. Blackwell Scientific Publ., London, p. 269-289

Noji, T., Passow, U., Smetacek, V. (1986). Interaction between pelagial and benthal during autumn in Kiel Bight. I. Development and sedimentation of phytoplankton blooms. Ophelia 26: 333-349

Pamatmat, M. M. (1968). Ecology and metabolism of a benthic community on an intertidal sandflat. Int. Revue ges. Hydrobiol. 53: 211-298

Pamatmat, M. M. (1978). Oxygen uptake and heat production in a metabolic conformer (Littorina irrorata) and a metabolic regulator (Uca pugnax). Mar. Biol. 48: 317-325

Pamatmat, M. M. (in press). Catalase activity and the hydrogen peroxide cycle. Arch. Hydrobiol. Beih. Ergeb. Limnol.

Pamatmat, M. M., Graf, G., Bengtsson, W., Novak, C. S. (1981). Heat production, ATP concentration and electron transport activity of marine sediments. Mar. Ecol. Prog. Ser. 4: 135-143

Revsbech, N. P., Jørgensen, B. B., Blackburn, T. H. (1979). Oxygen in the sea bottom measured with a microelectrode. Science 207: 1355-1356

Rubner, M. (1894). Die Quelle der tierischen Wärme. Z. Biol. 30: $73-142$

Schulz, R. (1983). Die Wirkung von Sedimentationsereignissen auf die benthische Lebensgemeinschaft. Ph.D. thesis, Kiel Univ.

Salonen, K. J., Sarvala, J., Hakala, I., Kiljanen, M.-L. (1976). The relation of energy and organic carbon in aquatic invertebrates. Limnol. Oceanogr. 21: 724-730

Smetacek, V., Bodungen, V. B., Knoppers, B., Neubert, H., Pollehne, F., Zeitzschel, B. (1980). Shipboard experiments on the effect of vertical mixing on natural populations in the central Baltic Sea. Ophelia 1 (Suppl.): 77-98

Smetacek, V., Hendrikson, P. (1979). Composition of particulate organic matter in Kiel Bight in relation to phytoplankton succession. Oceanologica Acta 2: 287-298

Wiegert, R. G. (1968). Thermodynamic considerations in animal nutrition. Am. Zool. 8: 71--81 